\title{
A Látrányi Puszta Természetvédelmi Terület pókfaunisztikai (Araneae) vizsgálatának eredményei
}

\author{
Szinetár CsabA ${ }^{1}$ És Keresztes BalázS ${ }^{2}$
}

\author{
'Department of Zoology Berzsenyi College, H-9701 Szombathely, Károlyi Gáspár tér 4., Hungary, \\ E-mail: szcsaba@deimos.bdtf.hu \\ ${ }^{2}$ University of Veszprém, Georgicon Agricultural Faculty Keszthely, Plant Protection Institute, \\ H-8360 Keszthely, Deák Ferenc út 16., Hungary, E-mail: facan-a@freemail.hu
}

SZINETÁR CS. KERESZTES B.: The results of the investigation of the spider fauna (Araneae) of the Látrányi Puszta Nature Conservation Area

Abstarct. The cxamination carried out in 2000-2002 yielded 152 spider species including Pirata insularis, which is new to the Hungarian spider fauna. The hitherto known spider fauna of Somogy county was enlarged by 24 newly detected species including two protected ones: Atypus piceus and Dolomedes fimbriatus. The high number of indigeneous species is probabaly due to the fact that the relatively small area is rather he-terogenic in the composition of its fauna. What's particularly valuable is the simultaneous presence of species typical of both dry sandy grasslands and of fen meadows.

Key words: sandy grasslands, fen meadows, protected spiders

\section{Bevezetés}

A Somogy megye területéről származó pókfaunisztikai kutatásokról összefoglaló közlemény jelent meg a közelmúltban (SzINETÁR 2001), a Somogy Fauna Katalógusa, "A $X X$. század végén Somogy megyéből ismertté vált állatfajok listája" címü kötetben (szerk. Ábrahám 2001). A fenti közlemény eredményei alapján megállapitható, hogy Somogy megye hazai viszonylatban egyike a legalaposabban kutatott területeknek. A XX. század végéröl származó szórványos adatgyüjtéseket követően több tájegység, elsősorban természetvédelmi terület, szervezett kutatási programjának keretében került sor alaposabb kutatásokra. Így kiemelendőek a Boronka-melléki Tájvédelmi Körzetben, a Zákány-Örtilosi dombokon, a Barcsi Tájvédelmi Körzetben, valamint Bélavár, Bolhó, Babócsa, Pótony és Tótújfalu körzetében végzett kutatások (SzINETÁR 1992, 1998, 2001). A Látrányi Puszta TT. kutatása szempontjából, területi közelsége okán is megemlitendők még Farkas János és munkatársainak 1993-94-ben Siófok közelében, a Törekihalastavak körzetében végzett gyüjtései. A kimutatott pókok, ugróvillások, valamint bogarak adatait egy publikációban közölték (FARKAS és mtsi. 1998). A hazai pókfauna irodalmi adatokon alapuló faunalistája 1999-ben készült el (SAMU és SzINETÁR 1999). Ennek alapján Magyarország mai határain belül 725 pókfajról rendelkezünk adattal. A Somogy megye területéről eddig ismertté vált 334 pókfaj a hazai fauna $46 \%$-a. Tekintettel arra, hogy a megye egy része mindmáig feltáratlannak tekinthető, ez a szám még jelentösen emelkedhet. Különösen érdekes lehet a késöbbiekben a Zselic, valamint a Balaton somogyi partvidékének a kutatása (SZINETÁR 2001). Ennek alapján is feltétlenül indokoltnak és ígéretesnek látszott a Balatonhoz közel esỏ és változatos élőhely-együttessel rendelkező Látrányi Puszta pókfaunisztikai kutatásának megkezdése, melyre a Somogy Megyei Múzeumok Természettudományi Osztályának irányításával indított kutatási 
program keretében került sor 2001-ben. A vizsgálatok feltételeit a Környezetvédelmi Minisztérium KAC pályázati támogatása biztosította. A gyüjtések a Duna-Dráva Nemzeti Park Igazgatóság engedélyével zajlottak.

Célkitüzések

A pókfaunisztikai vizsgálatok elsődleges célja a korábbi adatokkal nem rendelkező, ugyan kis területü, de erőteljesen heterogén természetvédelmi terület faunalistájának elkészítése. Továbbá célul tüztük ki az eltérő élőhely-típusok faunájának összevetését, valamint a korábban vizsgált hasonló jellegü somogyi területek faunájának ismeretében a megye pókfaunájáról alkotott kép további bővítését. A vizsgálatok figyelemmel voltak arra, hogy lehetőség szerint, e taxon esetében is konkrét javaslatokat fogalmazhassunk meg a terület természetvédelmi kezelésével, esetleges bővítésével kapcsolatban. A vizsgálati időszak (2000-2002) természetesen nem lehet elegendő a teljes faunalista elkészítéséhez, ugyanakkor a legtipikusabb élőhelyek jellemző faunaképének megismeréséhez már jó alapot adtak ezek a vizsgálatok is.

\section{Anyag és módszer}

A területről jelen kutatási program keretében készül első ízben növénycönológiai leírás. A mintavételi területek kiválasztása a terület bejárását követően történt meg. Segítséget nyújtott Ábrahám Leventének, a kutatási program szervezöjének javaslata a terület feltétlenül vizsgálandó élöhelyeire vonatkozóan. Fő szempontként azt vettük figyelembe, hogy a terület legjellemzőbb élőhelyei mind reprezentálva legyenek. A feldolgozott minták egy részét más kollégák gyüjtötték.

\section{Vizsgálati területek}

A közleményben szereplő eredmények több gyüjtő (a szerzők, Ábrahám Levente, Kondorosy Elöd, Farkas Sándor) 2000 és 2002 között végzett gyủjtéseinek feldolgozásából származnak. A feldolgozás alapját képező 41 önálló mintavételt az alábbi csoportosításban tárgyaljuk a fajok fogásainak bemutatásánál.

\section{Felvételezett élöhelyek:}

\section{Homoki gyepek}

(Homoki sztyepprét (Astragalo austriacae - Festucetum sulcatae Soó, 1957)

Elsősorban talajcsapdázás történt ebben a társulásban. Egyrészt saját üzemeltetésü csapdák voltak 2001 nyarán (2001. 07. 17. - 08. 09.), valamint Farkas Sándor 2002 júniusában alkalmazott csapdákat, melyek egy része szintén ebben a társulásban müködött. Fühálós és egyelö gyüjtések több időpontban történtek a terület homoki gyepeiben, az alábbi időpontokban: 2000. 05. 13.; 08. 02. ; 2001. 04. 13.; 06. 14.; 07. 03.; 07. 10.; 07. 17.; 07. 19.; 08. 09.

2. Láp-és mocsárrétek, magassásosok

A természetvédelmi terület északi, illetve déli részén lévő vizes élőhelyek közül a legjobb természetességi állapotúnak itélt két állományban történtek talajcsapdás gyüjtések. 2001 nyarán az északi rész zsombéksásos (Caricetum elatae Koch, 1926), valamint télisásos (Cladietum marisci Zobrist, 1935) társulásaiban. A téli sásos nádas nyáron is magas talajvízszinttel rendelkezik. A vizsgált területek közül saját megítélésem alapján ez a legkisebb zavarású élöhely. Ezen kívül a Visz község felé vezető közút keleti oldalán lévő lápréten müködtek még talajcsapdák (2001. 07. 17. - 08. 09.). Ez utóbbi területen 2002-ben Farkas Sándor szintén üzemeltetett csapdákat (2002. 07. 15 - 30.). Ez utóbbi láprét jellemző védett növénye a mocsári nőszőfü (Epipactis palustris). Megjegyzen- 


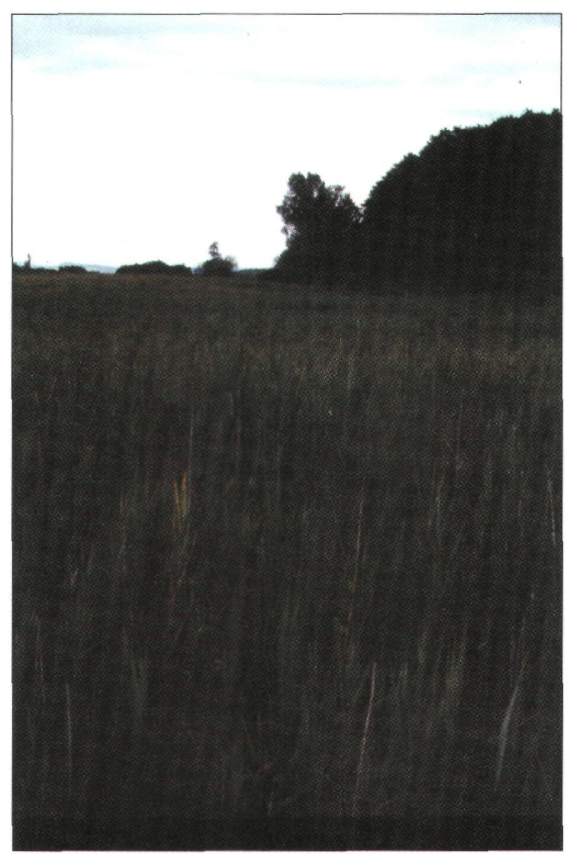

1.ábra: A Kolláti-legelô melletti nedves élőhelyegyüttes

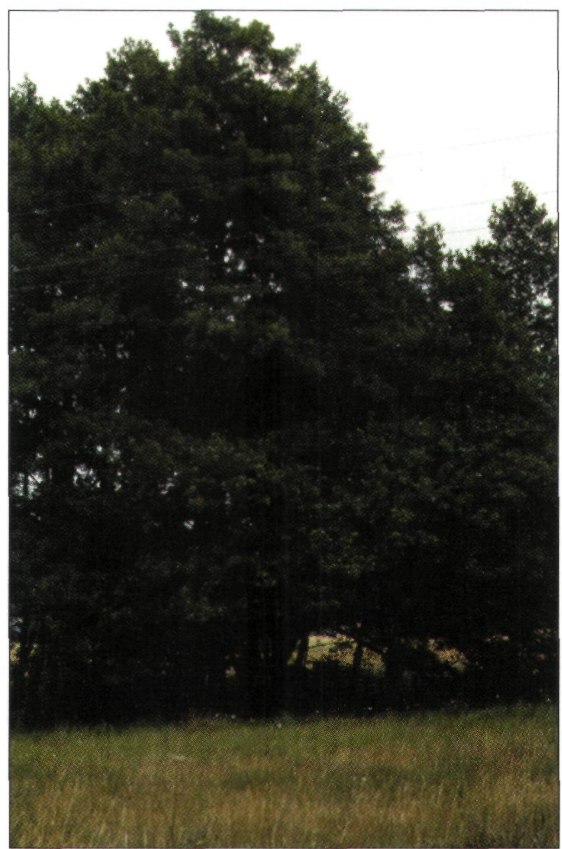

2. ábra: Égeres a Tetves-patak mentén 


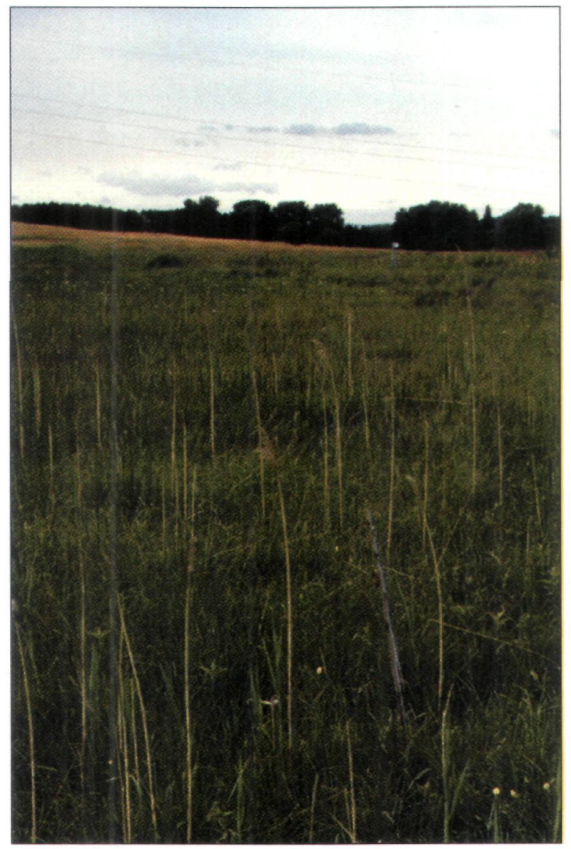

3. ábra: Fajgazdag láprét a közút és a patak között

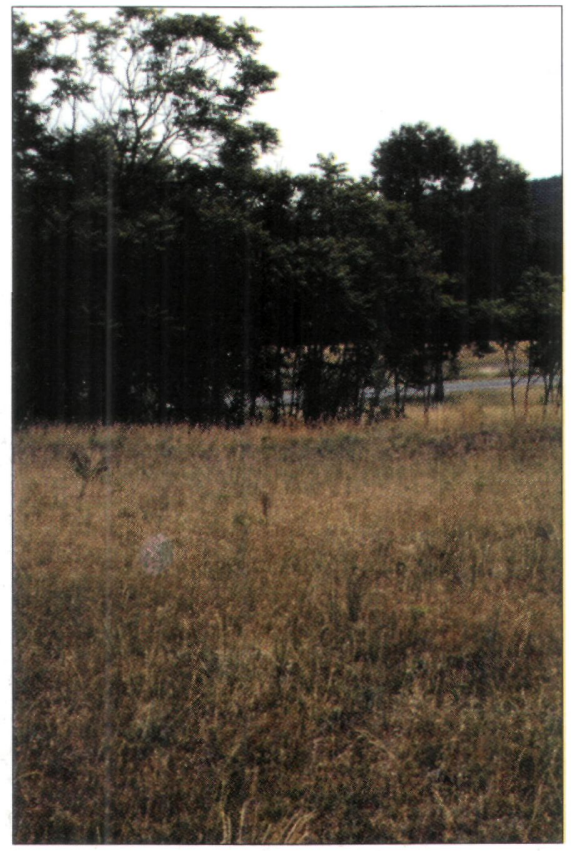

4. ábra: Homoki sztyepprét 
dő, hogy a gyep úthoz közeli oldalát (a rét szélességének legalább egyharmadát) vezetékfektetés során eröteljes zavarás (természetvédelmi szempontból súlyos károsodás) érte 2001 júniusának végén, illetve július első napjaiban. Fühálós és egyelő gyüjtések több időpontban történtek a terület láprétjein, illetve további vizes élőhelyein az alábbi időpontokban: 2000. 05. 13. ; 08. 02. ; 2001. 04. 13.; 06. 14.; 07. 03.; 07. 10.; 07. 17.; 07. 19.; 08. 09.

3. Égeresek és patakparti ligeterdö fragmentumok

Saját telepítésü talajcsapdákat 2001 nyarán, a TT déli részén, a Tetves-patak medrét kísérő égeresben üzemeltettünk (2001. 07. 17. - 08. 09.). 2002-ben szintén a patakot kísérő égeres, valamint füzes fragmentumokban csapdázott Farkas Sándor (2002. 07. 15 30.).

4. Nem vizes élöhelyekhez kötödö fásszárú társulások

2002-ben Farkas Sándor akácosban, cseres tölgyesben, erdeifenyvesben is üzemeltett talajcsapdákat (2002. 07. 15 - 30.).

Az 1999-es, 2000-es és 2001-es évben Ábrahám Levente, valamint Kondorosy Előd végzett növényzeti hálózásokat. Az általuk gyüjtött növényzeti anyagok feldolgozása alapján látható, hogy e gyüjtések részben szintén ezekről az élőhelyekről származtak, az alábbi időpontokból: 2000. 05. 13. ; 08. 02. ; 2001. 04. 13.; 06. 14.; 07. 03.; 07. 10.; 07. 19. A minták gyüjtőhelyének pontos azonosítása utólag már nem volt megvalósítható.

\section{Gyüjtési módszerek}

Barber-féle talajcsapdaként mindkét időszakban fedővel ellátott 3 deciliteres műanyag poharakat használtunk, ölőanyagként ecetsavat alkalmaztunk (a 2001-es saját üzemeltetésü csapdákhoz 20\%-os töménységü oldatot használtunk, míg Farkas Sándor 2002-ben 5\%-os oldatot használt. A 2001-ben üzemeltetett csapdák esetében úgy végeztük a mintavételezést, hogy azok négy tipikus élőhely talajlakó pókfaunájának közösségi vizsgálatára is alkalmasak legyenek (azonos gyüjtési ráfordítás és mintaszám). A talajcsapdás gyüjtésen kívül fühálózást és egyelést is végeztünk a területeken, valamint a saját mintavételeken túl, szintén fühálós gyüjtéseket bocsátottak rendelkezésünkre a területen dolgozó kollégák közül Ábrahám Levente és Kondorosy Elöd is.

Feldolgozás, határozás, nomenklatúra

A mintákat feldolgozásig $70 \%$-os etilalkoholba helyeztük. A állatok szétválogatása a BDF laboratóriumában történt, illetve a Somogy Megyei Múzeumtól is kaptunk válogatott talajcsapdás gyüjtéseket. A pókok determinálásához LoKSA $(1969,1971)$, HeIMER és Nentwig (1991), Nentwig és mtsi (2003), valamint RoBerts (1995) munkáit használtuk. A fajok elnevezésénél PLATNICK (1997) munkáját követjük. A korábbi hazai adatok tekintetében SAMU és SzINETÁr (1999), illetve SzINETÁR (2001) közleményét vettük alapul. Az adatok statisztikai feldolgozását a STATISTICA 5.0, valamint az Origin 7.0 programok segítségével végeztük. A statisztikai feldolgozáshoz a négy általunk csapdázott társulás esetében az azono\$ mintaszám érdekében 3-3 véletlenszerüen kiválasztott csapdát vettünk figyelembe.

\section{Eredmények}

A fentiekben leirt gyüjtési időpontokban alkalmazott mintavételezések során 1281 ivarérett, illetve faji szintig determinálható pók került begyüjtésre. Nem szerepelnek ebben az adatban azok a fiatal példányok, melyek determinálása legfeljebb csak genus szintig volt lehetséges. Néhány faj esetében a juvenilis, illetve subadult példányok már 
biztonsággal determinálhatók, így ezeket is tartalmazza az alábbiakban közölt faunalista (Araneus quadratus, Argiope bruennichi, Zilla diodia). A Cheiracanthium genus esetében csak fiatal példányok kerültek elö, a listába a genust felvettük (Cheiracanthium spp.). A többi taxon esetében legalább az egyik nemböl volt adult példány a gyüjtésekben. A viszonylag kis egyedszámú mintavétel ellenére kifejezetten fajgazdagnak tekinthető a gyüjtés, tekintettel arra, hogy az 1281 példány 152 pókfajt képvisel. A növényzeti, valamint egyelö gyüjtések során csak az adult példányok kerültek befogásra, így jelentősen csökkenthető volt a begyüjtött egyedszám. Az üzemeltetett talajcsapdák számát is igyekeztünk élöhelyenként minimalizálni, a területek kis kiterjedésére való tekintettel.

A Látrányi Puszta Természetvédelmi Területéröl kimutatott pókfajok és jellemzésük

\section{Torzpókfélék Atypidae}

Atypus affinis Eichwald, 1830

Egy hím példánya került elő a tölgyes talajcsapdázása során. Szórványos elterjedésü, tárnázó életmódú, védett hazai fajunk.

\section{Álkaszáspókok Pholcidae \\ Hoplopholcus forskali Thorell, 1871}

A Tetves-patak hídja alatt egyeléssel gyüjtött faj. Elökerülése az épített környezetnek köszönhetö. Hazánkban elsődlegesen épületszinantróp faj.

\section{Fojtópókok Dysderidae}

Dysdera ninnii Canestrini, 1868

Szórványos hazai előfordulású, erdőlakó faj. Száraz talajú elegyes erdőben kerültek példányai talajcsapdába (6 példány).

Harpactea rubicunda (C.L. Koch, 1838)

Egyike a leggyakoribb hazai erdei talajlakó pókjainknak. Ültetett fenyvesben és a fiatal tölgyesben gyüjtötte talajcsapda (7 példány).

\section{Derespókok Uloboridae \\ Uloborus walckenaerius (Latreille, 1806)}

A száraz homoki gyepek tipikus kísérő faja. Fühálózással és egyeléssel gyüjthető. Ivarérett példányai mindkét nemből előkerültek. Hazánkban a Duna-Tisza közén a leggyakoribb, de a Dunántúl déli részein, így például a Barcsi Tájvédelmi Körzet területén, valamint kisebb egyedszámban a Belső-Somogyra jellemző homoki gyepekben is ismert, pl. Boronka-melléki TK
(SzINETÁR, 1991). Jelenléte egyértelmüen utal e délebbi homoki területekkel szoros kapcsolatot mutató faunára (4 példány).

Törpepókok Theridiidae

Achaearanea tepidarionum (C.L. Koch, 1841)

A Tetves-patak hídja alatt egyeléssel gyüjtöttük egy példányát (számos további megfigyelése). Elökerülése az épített környezetnek köszönhető. Hazánkban elsődlegesen épületszinantróp faj.

Crustulina guttata (Wider, 1834)

Változatos, többnyire napos és száraz füves élőhelyekre jellemző faj. Egyelö gyüjtéssel került elő egy hím példánya gyepböl.

Enoplognatha ovata (Clerck, 1757)

Enoplognatha latimana Hippa \& Oksala, 1982

Mindkét Enoplognatha faj általánosan elterjedt hazánkban. Élöhelyválasztásuk eltérő. Az E. ovata a nedvesebb, míg az $E$. latimana a szárazabb területeket preferálja. A látrányi terület ismert természetföldrajzi adottságai alapján várható volt, hogy mindkét faj előkerül a területröl. (Hasonló együttes előfordulást tapasztaltunk a Barcsi Tájvédelmi Körzetben is (SzINETÁR 1998). Növényzeti hálózással gyủjthetök. Mindkét fajból 4 példány került elö.

Episinus angulatus (Blackwall, 1836)

Gyep- és cserjeszintben elterjedt hazai faj. Fühálózással került elö.

Euryopis flavomaculata (C.L. Koch, 1836)

Gyakori talajlakó faj. Füves (legelö) és részlegesen árnyékolt területek (égeres, füzes) talajcsapdáiban fordult elö. Nyílt füves élőhelyek talajlakó pókja. Egy példánya a terület északi részén lévő láprét talajcsapdájából került elö. 
Steatoda albomaculata (De Geer, 1778)

Nyílt száraz területek talajlakó faja. Egyeléssel gyüijtöttük egy példányát a legelön.

Steatoda bipunctata (Linnaeus, 1758)

A Tetves-patak hídja alatt egyeléssel gyüjtött faj. Előkerülése az épített környezetnek köszönhetö. Hazánkban részben épületekben, részben a szabad természetben, fóleg fakéreg alatt élö hemiszinantróp faj.

Steatoda phalerata (Panzer, 1801)

Talajlakó pókfajunk, melynek egy hím példánya homoki gyep talajcsapdázása során került elő.

Theridion impressum L. Koch, 1881

Általánosan elterjedt, gyakori növényzeten élö faj. A félszáraz és száraz gyepek száraz kóróin (a legeltetett gyepben is) gyakori (14 példány).

Theridion tinctum (Walckenaer, 1802)

Fák, különösen a tülevelüek lombozatán gyakori faj (1 példány).

\section{Törpe-keresztespókok Theridiosomatidae}

Theridiosoma gemmosum (L. Koch, 1877)

Nagy nedvesség igényü, növényzetlakó pókfajunk. Tipikus élöhelye a hazai patakjaink fölé hajló, sürü növényzet. Egy nőstény példánya a patak medrénél telepített csapdából került elö.

\section{Vitorláspókok Linyphiidae}

Araeoncus humilis (Blackwall, 1841)

Specifikus élőhelyi kötödést nem mutató gyakori faj. Egy példányát fúhálózással fogtuk.

Bathyphantes gracilis (Blackwall, 1841)

Magas páratartalmú élőhelyek gyakori faja. Lápréti talajcsapdák gyüjtötték négy példányát.

Centromerus sylvaticus (Blackwall, 1841)

Mérsékelten nedves élőhelyek, elsősorban erdők gyakori talajlakó pókja. A közepes bolygatást is jól tolerálja. A legelöi talajcsapdából került elő egy példánya.

Ceratinella brevipes (Westring, 1851)

Vizes élöhelyek mérsékelten gyakori talajlakó faja. A két csapdázott lápréten fogtuk 1-1 példányát.

Diplostyla concolor (Wider, 1834)

Nedves erdők, árnyékos vízparti élőhelyek rendkívül gyakori talajlakó faja. 15 ivarérett példányát égeresben, illetve a füzesben fogtuk.
Gonatium paradoxum (L. Koch, 1869)

Specifikus élöhelyi kötödést nem mutató gyakori faj. Az akácosban került elö három példánya.

Gongylidiellum murcidum Simon, 1884

Nádasok, mocsárrétek más vizes élőhelyek mérsékelten gyakori faja. A "nőszőfüves" lápréten talajcsapda fogta egy példányát.

Hylyphantes nigritus (Simon, 1881)

Mérsékelten nedves erdők rendkívül ritka faja. Egyetlen példánya fühálózott mintából került elö.

Lepthyphantes angulipalpis (Westring, 1851)

Specifikus élöhelyi kötődést nem mutató, erdei avarban élő gyakori faj. Egy példányát a fenyvesben müködő talajcsapda gyüjtötte.

Lepthyphantes flavipes (Blackwall, 1854)

Változatos erdök avarszintjében élő gyakori faj. Égeresben fogtuk egy példányát.

Meioneta mollis (O.P.-Cambridge, 1871)

Rétek, erdőszélek, változatos füves élöhelyek faja. Nedves és viszonylag száraz élöhelyeken (például gabonaföldeken) is jelen van. Lápréten fogtuk két példányát.

Meioneta rurestris (C.L. Koch, 1836)

Specifikus élőhelyi kötödést nem mutató faj. Egyike a leggyakoribb hazai pókjainknak. Szinte bármely élöhelytípusban jelen lehet. A homoki gyepben került elö három példánya.

Microneta viaria (Blackwall, 1841)

Közepesen nedves erdök avarszintjében élö gyakori faj. Tölgyesben ( 2 példány) és a füzesben (1 példány) fogtuk.

Neriene clathrata (Sundevall, 1830)

Gyakori, elsősorban erdei faj. Többnyire mérsékelten nedves élőhelyeken talajközeli növényeken szövi hálóját. Egy példánya akácosban került elő.

Neriene radiata (Walckenaer, 1841)

Félárnyékos erdők és erdőszegélyek közepes nedvességigényü gyakori faja. Egy példánya fühálós mintában fordult elö.

Oedothorax agrestis (Blackwall, 1853)

Nedves füves és ligetes erdei élöhelyek mérsékelten gyakori talajlakó pókja. Magassásosban fogtuk egy példányát talajcsapdával. 
Pelecopsis parallela (Wider, 1834)

Nyílt füves élöhelyek közepesen gyakori faja. Az extrém száraz gyepektől a nedves réteken át, egyes agrár-ökoszisztémákig (például lucernaföldek) egyaránt jelen van. A Látrányi Puszta TT-én a homoki gyepben viszonylag gyakori fajnak bizonyult ( 7 példány).

Pocadicnemis juncea Locket \& Millidge, 1953

Nedvességkedvelő faj. Lápréteken, nedves kaszálókon általánosan jelen van. Korábban nem különítették el a hasonló élőhelyválasztású, morfológiailag is rendkívül közelálló Pocadicnemis pumila-tól (Blackwall, 1841), így a hazai irodalomban kevés bizonyított elöfordulási adatáról tudunk. Az elmúlt évek vizsgálatai alapján a vizes élöhelyek tipikus faja. Számos új előfordulási adata várható. A láprét talajcsapdájából került elő egy példánya.

Stemonyphantes lineatus (Linnaeus, 1758)

Roppant változatos élőhelyekröl ismerjük. A száraz gyepektől a lápréteken át a ligetes erdökig sok helyütt jelen lehet e viszonylag nagy testü, talajfelszín közelében élő vitorláspókunk. Egy példány az akácos csapdájából került elö.

Trematocephalus cristatus (Wider, 1834)

Nincs specifikus élőhelyi kötődése a fajnak. Növényzeten él változatos szituációkban, hazánkban közepesen gyakori. Egy példánya növényzeti hálózással került elő.

Walckenaeria atrotibialis (O.P.-Cambridge, 1878)

Széles élőhelyspektrummal rendelkezö, közepes nedvességigényü talajlakó pók. Közepesen gyakori. A Látrányi Puszta TT. láprétjeinek, magassásosainak és csatlakozó élöhelyeinek jellemző faja (11 példány).

Walckenaeria furcillata (Menge, 1869)

Gyakori, viszonylag tág élőhelyválasztású erdőlakó fajunk. Tölgyes talajcsapdájából került elő egy példánya.

Walckenaeria mitrata (Menge, 1868)

Mérsékelten nedves erdők avarlakó, gyakori hazai pókja. Lápréti elöfordulása ( 1 példány) a nedves erdőfragmentumok közelségével magyarázható.

Walckenaeria unicornis O.P.-Cambridge, 1861

Vizes élőhelyek ritka talajlakó faja. Magassásosban került elő egy példánya. Walckenaeria vigilax (Blackwall, 1853)

Nagy nedvességigényü, füves élőhe- lyekre jellemző, közepesen gyakori faj. Szintén a magassásosban fogtuk egy példányát.

Állaspókok Tetragnathidae

Metellina mengei (Blackwall, 1869)

Gyakori, kora nyári ivarérésü kerekhálós pókunk. Nyílt és erdei élöhelyeken egyaránt jelen van. Fühálózással két példányát fogtuk.

Pachygnatha listeri Sundevall, 1830

Árnyékos és nedves erdők talajszintjére jellemző faj. A füzesben fogta egy példányát talajcsapda.

Tetragnatha extensa (Linnacus, 1758)

Vizes élöhelyeinkhez kötődö leggyakoribb állaspókfajunk, mely az árnyékolt zónákat kerüli. Napos patakparti növényzeten gyakori országszerte. A Tetves-patak mentének is jellemző faja. Három példányát itt fogtuk egyeléssel.

Tetragnatha montana Simon, 1874

Szintén a víz közelsége a meghatározó környezeti tényező e faj élőhelyválasztásában is. Az előző fajjal ellentétben igényli az árnyékolást, így nedves erdők aljnövényzetében és az árnyékolt vízparti növényzeten általánosan elterjedt, gyakori faj. Négy példányát növényzeti hálózással fogtuk.

Tetragnatha obtusa C.L. Koch, 1837

$\mathrm{Az}$ előző állaspókoktól eltérően a víz nem játszik döntő szerepet a faj élöhelyválasztásásban. Magasabb szinteken, akár a lombkoronaszintben is jelen lehet. Többek között a fák koronájában is. Három példánya lombozati hálózásból került elö.

\section{Keresztespókok Araneidae}

Agalenatea redii (Scopoli, 1763)

Meleg, napsütötte, füves élöhelyek gyakori keresztespókja. A láprétektől a nyílt homokpusztai gyepekig számos gyeptípusban gyakori lehet. A Látrányi Puszta TT-én főleg a lápréteken, valamint a legelöként hasznosított gyepekben jellemző (15 begyüjtött, valamint számos további megfigyelt példány).

Araneus diadematus Clerck, 1757

Legismertebb hazai keresztespókunk. Erdőszéleken, parkokban, kertekben egyaránt gyakori. Egy ivarérett példány került begyüjtésre. 
Araneus quadratus Clerck, 1757

Nedves rétek, magaskórósok helyenként kifejezetten gyakori faja. Igényli a jó megvilágítást, az árnyékos helyeket kerüli. Ivarérési ideje a kora ösz, így a nyári mintavételeinkben különböző fejlettségü fiatal példányai fordultak csak elö, elsősorban a terület északi részén lévő lápréten.

Araneus sturmi (Hahn, 1831)

Közepesen gyakori erdőlakó faj. Elsősorban tülevelü fákon él. Egy példányát lombozati hálózással fogtuk.

Araniella cucurbitina (Clerck, 1757)

Gyakori cserje- és lombkoronaszintben lakó fajunk. Elsősorban az erdőszegélyeket kedveli. Két ivarérett példányát lombozati hálózással fogtuk.

Araniella displicata (Hentz, 1847)

Mérsékelten gyakori növényzeti faj. Cserje- és lombkoronaszintben él. Egy példánya lombhálózással került begyüjtésre.

Araniella opistographa (Kulczynski, 1905)

Gyakori cserje- és lombkoronaszintben lakó fajunk. Elsősorban az erdőszegélyeket kedveli. Három ivarérett példányát lombozati hálózással fogtuk.

Argiope bruennichi (Scopoli, 1772)

Nyílt füves élöhelyek helyenként tömeges faja. Hazánkban föleg nádasok szegélyében lévő mocsár- és lápréteken lehet különösen gyakori. A Látrányi Puszta TT. láprétjein, ezek közül is különösen az északi területen fordul elö nagy számban. (A gyüjtött mintákban 48 példány, valamint számos további megfigyelt egyed).

Gibbaranea bituberculata (Walckenaer, 1802)

Meleg napos gyepek, erdőszélek talajközeli növényein élö kistestü keresztespókja. Fühálózással fogtuk egy példányát.

Hypsosinga heri (Hahn, 1831)

Vízparti növényzeten gyakori keresztespókunk. Főleg az állóvizek szegélyében él. A területen átfolyó Tetves-patak parti zónájában is tipikus az előfordulása ( 5 példány).

Larinioides folium (Schrank, 1803)

A nádasokhoz kötődő nagytestü kerekhálós fajunk. A patak szegélyében (a Visz határában lévő híd közelében) egyelö gyüjtéssel fogtuk egy nöstény példányát.
Mangora acalypha (Walckenaer, 1802)

A faj magyar nevéhez hüen, bármely füves élőhelyen gyakori fajként találkozhatunk a réti keresztespókkal. A Látrányi Puszta TT. valamennyi lágyszárú társulásában él (18 fúhálózott példány).

Neoscona adianta (Walckenaer, 1802)

Közepesen gyakori faj. Nyílt napos élöhelyeken néha nagy számban találkozhatunk vele. A Dunántúl egyes homoki élőhelyein is jellemző e lokális gyakoriság. A Barcsi Tájvédelmi Körzet darányi területén, valamint itt Látrányban is gyakori. Fühálós mintában 14 példánya került elő.

Singa hamata (Clerck, 1757)

A vizes élöhelyekhez kötődő gyakori faj. Nádasokban, vízpartokon, magassásosokban egyaránt tipikus. Három példánya fühálózással került elö.

Zilla diodia (Walckenaer, 1802)

Napos erdőszegélyek fáinak tipikus lombozati faja. Két példány lombozati hálózással került elő.

\section{Farkaspókok Lycosidae}

Alopecosa cuneata (Clerck, 1757)

Napos erdőszegélyek, változatos füves élőhelyek gyakori faja. Környezetének páratartalmára kevéssé érzékeny. Öt kifejlett példánya a nem "vizes" erdőkből és a láprétröl került elö.

\section{Alopecosa pulverulenta (Clerck, 1757)}

Változatos gyepekben, valamint kevéssé zárt erdőkben egyaránt elterjedt gyakori farkaspókunk. Egy példánya a fiatal cseres-tölgyesben került talajcsapdába.

Arctosa lutetiana (Simon, 1876)

A faj mérsékelten gyakori hazánkban. Rendkívül eltérö habitatokban fordul elö. Helyenként gyakori lehet. Több helyen láperdőkből (Ocsa, LoKSA 1971, Bolhó és Töreki, SzINETÁR 1998), de ugyanakkor bokorerdőkből is vannak adatai (LoKSA 1971). BUCHAR és RŮžIČKA (2002) mint szárazságkedvelő (türő) fajt tipizálja, és erdős-sztyeppeket jelöli meg mint tipikus élőhelyet. A Látrányi területen fogott 10 ivarérett példány az égeresben üzemeltetett csapdákban szerepelt.

Arctosa maculata Hahn, 1822

Erősen nedves füves élőhelyek tipikus, viszonylag nagytestü farkaspókja. A csap- 
dázott lápréteken gyüjtött 21 ivarérett példánya alapján jellemzőnek mondható a Látrányi Puszta TT-re.

Aulonia albimana (Walckenaer, 1805)

Speciális élőhelyi kötődést nem mutató farkaspókunk. Egy példánya a patakparton müködö talajcsapdából került elö.

Pardosa alacris (C.L. Koch, 1833)

A hazai erdök egyik domináns farkaspókja. Korábban nem különítették el a Pardosa lugubris-tól (Walckenaer, 1802), így a két faj pontos hazai elterjedésével és élőhely-választásával jelenleg még nem vagyunk tisztában. A hímekre alkalmazott differenciális bélyegek alapján, a területen csak $P$. alacris példányt találtunk. Tíz hím példány mellett 57 nöstény (P. alacris sensu lato) fogtak a talajcsapdák a szárazabb elegyes erdőktől az égereseken át a füzesig. BuCHAR és RŮžIČKA (2002) utal rá, hogy a $P$. alacris a száraz erdőkben, míg a $P$. lugubris a száraztól a nedves erdőkig számos erdőtípusban elöfordul. A két faj élöhely-preferenciájának vizsgálata kellö mennyiségü hazai adat birtokában, a későbbiekben feltétlenül vizsgálandó.

Pardosa bifasciata (C.L. Koch, 1834)

Palearktikus elterjedésü, nyílt homoki élőhelyeket preferáló faj. A homoki gyep talajcsapdáiban került elö 5 nőstény példánya. Föleg jó természetességü élőhelyekre jellemző faj. Jelen gyepekröl ez kevéssé mondható el (legeltetés, gyomosodás). Feltételezhetö, hogy a gyepek állapotának javulását növekvő abundanciája jelezné.

Pardosa maisa Hippa és Mannilla 1982

E nedves élőhelyekre jellemző farkaspókfaj csak a közelmúltban vált ismertté hazánkból (SzINETÁr és GUITPRECHT 2001). Mostanra a Dunántúl számos pontjáról van már adatunk a fajról, melynek legtipikusabb élőhelyei a Közép-Dunántúl kiszáradó, kékperjés láprétjei. Mindössze 1 példánya került elő a Látrányi Puszta TT. területéröl a magassásosban üzemelö talajcsapdából.

Pardosa prativaga (L. Koch, 1870)

Nagy nedvességigényü faj. A teljes megvilágítást kerüli, így a jól záródó láp- réti gyepben megtalálja a kedvezö életfeltételeit. Három példánya itt került elő talajcsapdából.

Pardosa riparia (C.L. Koch, 1833)

Füves élőhelyek mérsékelten gyakori farkaspókja. Nedves gyepeken kívül a száraz kaszálókon is jelen lehet. Három példányát a Látrányi Puszta TT. déli nőszőfüves láprétjén, illetve a közeli magassásosban fogták a talajcsapdák.

Pirata hygrophilus Thorcll, 1872

Gyakori, nagy nedvességigényü kalózpókunk. A vizsgált láprétek egyik leggyakoribb faja (70 ivarérett példány).

Pirata insularis Emerton, 1885

Kimagaslóan nagy egyedszámban elökerült faunánkra nézve új farkaspókfaj. Talajcsapdáink 102 hím példányát gyüjtötték, ezzel a második leggyakoribb talajlakó fajnak bizonyult. Élőhelye elsődlegesen a terület északi részén lévő, mély fekvésü láprétje. Holarktikus elterjedésü, tipikusan higrofil faj. A két csapdázott élöhelyen egyaránt nagy egyedszámban kerültek elő adult hím példányok, jelezve, hogy a faj a szaporodási időszaka feltételezhetően július második felében van. A faj hazai elökerülése annak ellenére váratlan volt, hogy több közép-európai országból is ismert volt már (Románia, Németország). A korábbi határozók föleg Észak-Európából jelezték, mint tipikus nyílt lápokon, tőzegmohás dagadólápokon élö fajt (HEIMER és Nentwig 1991, RoBerts 1995). FuHN (1971) Románia területéről, több gyüjtőhelyröl is közli, élöhelyként nyílt égerlápokat említ. Sík-, domb- és hegyvidéki lelőhelyekről egyaránt előkerült. Meglepő, hogy a hazánknál jelentősebb kutatottsággal rendelkező Csehország, valamint Szlovákia területéröl a legfrissebb munkák sem közlik (BUCHAR és RÚŽIČKA 2002, GAJDOS et al. 1999). A faj előfordulása annak ismeretében is különösen érdekes, hogy az elmúlt néhány évben a Dunántúlon (Bakonyalján, Kelet-Zalai dombság területén), illetve a Duna-Tisza közének kékperjés láprétjein folytak alapos talajcsapdás gyüjtések, melyek során nem került elö ez a faj, ugyanakkor más, szintén hazai faunára új, nagy nedvességigényü farkas- 
pókot (Pardosa maisa) sikerült kimutatni hasonlóan magas abundancia értékekkel (SZINETÁr és GUITPRECHT 2001). A faj ökológiájának és elterjedésének további vizsgálata feltétlenül indokolt.

Pirata latitans (Blackwall, 1841)

Nedves rétek és lápok tömegesen előforduló farkaspókja. A Látrányi Puszta TT. láprétjeinek leggyakoribb pókja. Mindkét vizsgált lápréten ez volt a domináns faj (264 ivarérett példány). A terület jó vizellátottságának kitünő jelzője.

Trochosa ruricola (De Geer, 1778)

Gyakori, közepes nedvességigényü farkaspókunk. Lápréteken, magassásosokban és a nedves erdőkben (égeres, füzes) egyaránt gyakori volt (64 hím példány). A lápréteken fogott $T$. ruricola és $T$. terricola hímek előfordulási arányai alapján valószínüsithetö, hogy a lápréteken fogott nöstények többsége szintén $T$. ruricola volt. (Megj: a Trochosa genus nőstényeinek fajszintü elkülönítése morfológiai bélyegek alapján bizonytalan, így az együttesen előforduló hímek ismeretében, illetve arányában lehet csupán következtetni a faji hovatartozásukra). A 27 ivarérett nőstényböl 21 lápréten, 6 további magassásosban került elő.

Trochosa spinipalpis (F.O.P.-Cambridge, 1895)

Fény- és nedvességkedvelö faj. Az európai Trochosa fajok közül ez a faj tipikusan kötődik a lápokhoz, láprétekhez és vízpartokhoz. Élöhelyének bolygatását csak mérsékelten tolerálja. A Bakonyalja láprétjein általánosan elterjedt. A Boronka-melléki TK-ban, illetve a Dráva-mentén Bélavárnál szintén előkerült. Egy hím példánya került elő a Látrányi Puszta TT. északi részének télisásos láprétjén.

Trochosa terricola Thorell, 1856

A Trochosa fajok közül ez a faj mutat legkevéssé kötődést a vízhez. Agrárélöhelyeken és változatos erdei élőhelyeken egyaránt jelen van. A nem vizes élőhelyhez kötött erdökben 30 , a többi élöhelyröl további 8 hím példánya került elö. A bolygatást, valamint a kiszáradást növekvő abundanciával jelzi.

Xerolycosa miniata (C.L. Koch, 1834)

Száraz, nyílt élőhelyek faja. Egy példányát homoki gyep talajcsapdája fogta.
Xerolycosa nemoralis (Westring, 1861)

A száraz, füves élöhelyek jellemző faja. A homoki gyepek gyakori pókfaja (13 példány).

\section{Csodáspókok Pisauridae \\ Dolomedes fimbriatus (Clerck, 1757)}

Két fiatal példány került fühálózással befogásra. A mintázat, valamint az élőhely alapján csaknem biztonsággal állitható, hogy a szegélyes vidrapókról van szó. Nyílt vízfelszínnel rendelkező élőhely (a Tetves-patak medrét kivéve) nincs a területen, így a parti vidrapók (D. plantarius) elöfordulása kevéssé valószínü ezen a területen. Mindkét vidrapók fajunk védett.

Pisaura mirabilis (Clerck, 1757)

Gyakori nappali vadászpókunk. Mérsékelten nedves és száraz gyepekben, kevéssé zárt erdőkben és szegélytársulásokban egyaránt általánosan elterjedt. Egy nőstény példányát talajcsapdával, fiataljait fühálózással gyüjtöttük.

\section{Hiúzpókok Oxyopidae \\ Oxyopes lineatus Latreille, 1806}

Elsősorban az Alföld homokos területeire jellemzö, melegkedvelö faj. Somogyból Darány, Nagybajom, valamint Tótújfalú területéről volt ismert, hasonló jellegü homoki gyepekből. Öt példánya a homoki gyep fúhálózott mintáiból került elö.

\section{Zugpókok Agelenidae}

Agelena labyrinthica (Clerck, 1757)

Az illó tölcsérpók a sürü gyepszintben szövi nagyméretű tölcsérhálóját. Egy példányát egyeléssel fogtuk.

Tegenaria campestris C.L. Koch, 1834

Nevével ellentétben elsősorban erdei élőhelyekre, gyakorta fenyvesekre jellemzö faj. A talajfelszín közelében alacsonyan futó ágak között szövi hálóját. Négy példánya az erdeifenyvesben müködő talajcsapdákkal került befogásra.

\section{Hamvaspókok. Dictynidae \\ Dictyna arundinacea (Linnacus, 1758)}

Rendkívül gyakori hamvaspókunk. Füves élöhelyeken rendkívül változatos körülmények között fordulhat elő a nádasoktól egészen a száraz gyepekig. Fühálózással két példányát gyüjtöttük. 
Dictyna latens (Fabricius, 1775)

Száraz és nyillt füves élőhelyeken a talajfelszín közelében élö, mérsékelten gyakori faj. Egy példány fühálózással került elő.

\section{Avarpókok Liocranidae}

Agraecina striata (Kulczynski, 1882)

Elsősorban ártéri ligeterdők talajfelszíni faja. Egy példányát füzesben kihelyezett csapda gyüjtötte.

Agroeca brunnea (Blackwall, 1833)

A barna avarpók egyike a leggyakoribb erdei talajlakó pókjainknak. Három példányát elegyes erdö talajcsapdái fogták.

Agroeca cuprea Menge, 1873

Nyílt és félárnyékos területek tágtürésü faja. A legelőn müködő csapdák gyưjtötték három példányát.

Phrurolithus festivus (C.L. Koch, 1835)

Speciális élőhelyi kötődést nem mutató, elsősorban erdőkben élö pókunk. Egy hím példányát égeres talajcsapdája fogta.

\section{Kalitpókok Clubionidae}

Cheiracanthium spp. juv.

A genusból csak fiatal példányok kerültek elő növényzeti hálózások során. Minden bizonnyal több dajkapókfaj is él a területen.

Clubiona brevipes Blackwall, 1841

Speciális élőhelyi kötődést nem mutató, mérsékelten gyakori kalitpókunk. Egy példányát magassásosban fogtuk.

Clubiona leucaspis Simon, 1932

Tipikusan fásszárúakon élö, kisméretü kalitpók. Megjelenésében rendkívül közel áll hozzá a talajlakó Clubiona genevensis L. Koch, 1866. Biztos elkülönítésük csak ivarszervi vizsgálattal valósítható meg. Egy nöstény példánya lombozati hálózásból származik.

Clubiona lutescens Westring, 1851

Változatos élőhelyeket benépesitő faj, specifikus igényei nincsenek. Egy példányát fühálózással fogtuk.

Clubiona pallidula (Clerck, 1757)

Gyakori nagytestủ kalitpókunk. Elsősorban fák kérgén él, de az erdők avarszintjében is jelen van. Egy példányát égeresben talajcsapdával, egyet pedig erdei lombhálózással fogtuk.

Clubiona stagnatilis Kulczynski, 1897

Tipikusan vizes élőhelyekhez kötődő gyepszinti faj. Egy példányát magassásosban fogtuk.

\section{Búvópókok Zodariidae}

Zodarion germanicum (C.L. Koch, 1837)

Leggyakoribb búvópókfajunk. Elsősorban erdők avarszintjében él, de változatos, olykor degradált gyepekben is jelen van. Cseresben, illetve a patakparton müködő csapdák gyưjtötték 1-1 példányát.

\section{Kövipókok Gnaphosidae \\ Berlandina cinerea (Menge, 1872)}

Tipikusan homoki élőhelyekre jellemző, relatív nagytestü kövipókunk. A homoki gyep talajcsapdái fogták három adult nőstény példányát. Barcsról és Nagybajomból ismertük már korábban is somogyi elöfordulását.

Drassodes pubescens (Thorell, 1856)

Meleg- és szárazságkedvelö talajfelszíni faj. 1 példánya egyelésel került elö.

Drassyllus lutetianus (L. Koch, 1866)

Nagy nedvességigényü kövipókunk. Mocsárrétek és nádasok jellemző faja. Egy példányát a magassásosban müködő talajcsapda gyüjtötte.

Haplodrassus moderatus (Kulczynski, 1897)

Nagy nedvességigényü, viszonylag ritka talajlakó faj. Két példánya szintén a magassásosban került elö.

Haplodrassus silvestris (Blackwall, 1833)

Gyakori erdőlakó faj. Elsősorban az árnyékolást igényli, a nedvességigénye kevéssé specifikus. Az égeresben, a füzesben, valamint a tölgyesben egyaránt fogtuk 1-1 példányát talajcsapdával.

Micaria romana L. Koch, 1866

Közép-Európa déli területeinek viszonylag ritka pókja. Egy példányát homoki gyepben fogtuk. Kevés hazai adata van. Kerekes (1988) Bugacon szintén homokpusztai gyepben gyüjtötte.

Trachyzelotes pedestris (C.L. Koch, 1837)

A leggyakoribb kövipók a területen. A lápréteken és a füzesben egyaránt gyakori volt (48 ivarérett példány).

Zelotes apricorum (L. Koch, 1876)

Változatos élőhelyeken előforduló faj. A Látrányi Puszta TT nem vizes élőhelyekhez kötődő erdeiben viszonylag gyakori (tíz ivarérett példány).

Zelotes aurantiacus Miller, 1967

Melegkedvelö, ritka faj. Egy példányát égeresben lévö talajcsapda gyüjtötte. A 
szomszédos szárazabb élőhelyről származhatott a példány.

Zelotes latreillei (Simon, 1878)

Nyílt és félárnyékos élőhelyek közepesen gyakori faja. Két példányát lápréten müködő talajcsada gyüjtötte.

Zelotes longipes (L. Koch, 1866)

Meleg és száraz füves élőhelyek pókja. Három példánya homoki gyepben talajcsapdával, illetve egyeléssel került befogásra.

\section{Párducpókok Zoridae}

Zora spinimana (Sundevall, 1833)

Leggyakoribb hazai párducpókunk. 1-1 példányát a füzesben, valamint az égeresben müködő talajcsapdák fogták.

\section{Vadászpókok Heteropodidae}

Micrommata virescens (Clerck, 1757)

Közepes nedvességigényü nappali vadászpókunk. Üde, sűrü gyepekben, erdőszéleken, illetve ligetes erdőkben él. Egy nőstény példánya fühálózással került elö.

\section{Futópókok Philodromidae}

Philodromus albidus Kulczynski, 1911

Viszonylag ritka lombozati futópókunk. A morfológiailag roppant hasonló $P h$. rufustól csak az ivarszervi preparátumok alapján különíthető el. Egy nőstény példánya kopogtatással került befogásra.

Philodromus cespitum (Walckenaer, 1802)

Leggyakoribb hazai futópókunk. Cserjeés lombkoronaszintben egyaránt általánosan elterjedt, nem mutat speciális kötődést növényfajhoz, gyümölcsösökben is gyakori. Egy nőstény példányát egyeléssel fogtuk cserjeszintben.

Philodromus poecilus (Thorell, 1872)

Rendkívül kevés adattal rendelkezünk a faj hazai előfordulásáról. Egy nőstény példányát növényzeti hálózással fogtuk. Rit$\mathrm{ka}$, ismeretlen biológiájú faj.

\section{Tibellus maritimus (Menge, 1875)}

Tibellus oblongus (Walckenaer, 1802)

A két Tibellus faj (sovány karoló) hazánkban hasonló gyakorisággal fordul elő füves élőhelyeken. Az előbbiböl két, utóbbiból három ivarérett példány került elő fühálózással.

\section{Karolópókok Thomisidae}

Heriaeus graminicola (Doleschall, 1852)

Gyepszinti, melegkedvelő faj. Egy példánya fühálózással került begyüjtésre.

\section{Misumena vatia (Clerck, 1757)}

Változatos füves élőhelyek általánosan elterjedt karolópókja. Kifejlett példányai tipikusan virágokban élnek. Ivarérett (14 példány) és számos fiatal példányát elsősorban a láprétek fühálózása során fogtuk.

Misumenops tricuspidatus (Fabricius, 1775)

Az alakoskodó karolópók a gyep-, a cserje-, valamint a lombkoronaszint gyakori karolója. Kopogtató-, és fühálóval különböző növényekröl öt példánya került begyüjtésre.

Ozyptila praticola (C.L. Koch, 1837)

Gyakori talajlakó faj, mely a mérsékelten, valamint erősen nedves erdők tipikus pókja. Különösen az égeresben fordult elő nagy egyedszámban (54 ivarérett példány).

Ozyptila trux (Blackwall, 1846)

Nagy nedvességigényü, füves élőhelyekhez kötődő faj. Hat példánya lápréten és magassásosban került talajcsapdába.

Runcinia grammica (C.L. Koch, 1837)

Gyakori, melegkedvelő gyeplakó faj. A Látrányi Puszta TT. egyik leggyakoribb karolópókja. A fühálózással gyüjtött mintákban nagy egyedszámban volt jelen (40 ivarérett példány).

Thomisus onustus Walckenaer, 1806

A Misumena vatia mellett a második leggyakoribb viráglakó karolópókunk. Változatos színü példányai elsősorban a virágos növényeken várakoznak táplálékállataikra (11 példány).

Tmarus piger (Walckenaer, 1802)

A csúcsos karolópók föleg lombhullató fák lombozatán élő, általánosan elterjedt faj. Egy nőstény példánya vegyes lombozati mintából került elö.

Xysticus audax (Schrank, 1803)

Gyakori talajközelben élö karolópók. Egy példányát egyeléssel fogtuk.

Xysticus cristatus (Clerck, 1857)

Változatos élöhelyek talajfelszíni, illetve részben gyepszinti faja. Két példányát fühálózással fogtuk. 
Xysticus kochi Thorell, 1872

Speciális kötődést nem mutató gyakori

faj. Egy példánya fưhálós mintából került elő.

Xysticus lanio C.L. Koch, 1835

Viszonylag gyakori talajlakó faj. Talajcsapdával 1-1 példánya égeresben, illetve a tölgyesben került begyüjtésre.

Xysticus luctator L. Koch, 1870

Erdei talajlakó faj. 1-1 példánya került elő égeresben, illetve akácosban.

Xysticus ninnii Thorell, 1872

Közép-, valamint Dél-Európára jellemző száraz gyepekhez kötódö viszonylag nagytestü karolópók. A homoki gyep csapdáiban szerepelt a vizsgálati időszakban gyakori fajként. A négy csapda 17 adult példányát gyüjtötte. Korábban Barcsnál és Bélavárnál szintén előkerült.

Xysticus striatipes L. Koch, 1870

Nyílt, száraz élőhelyek faja. Egy példányát egyeléssel fogtuk.

Xysticus ulmi (Hahn, 1831)

Tipikusan növényzeten élő karolópók, mely a közepesen nedves, üde élöhelyeken gyakori. Fühálóval fogtuk két példányát.

\section{Ugrópókok Salticidae}

Aelurillus v-insignitus (Clerck, 1757)

Száraz gyepekre jellemző talajfelszíni pók. Két példányát a homoki gyepben müködő csapdák gyüjtötték.

Bianor aurocinctus (Ohlert, 1865)

Lápi környezetben és félszáraz gyepekben egyaránt előforduló talajfelszíni ugrópókunk. Egy példányát egyeléssel fogtuk.

Carrhotus xanthogramma (Latreille, 1819)

Melegkedvelö, lombozatlakó faj. Erdőszéleken és gyümölcsösökben is gyakori lehet. Egy példánya akácosban került elő.

Dendryphantes rudis (Sundevall, 1832)

Lombozatlakó fajunk, mely tipikusan fenyőféléken él. Egy példánya lombozati hálózásban szerepelt.

Evarcha arcuata (Clerck, 1757)

Egyike a leggyakoribb ugrópókjainknak. Elsősorban a neves réteken él. Hat példánya a láprétek fühálós mintáiban szerepelt.
Evarcha falcata (Clerck, 1757)

Gyakori gyepszinti faj. Speciális élőhelyi preferenciája nincs. Egy példánya lápréti hálózással került befogásra.

Evarcha laetabunda (C.L. Koch, 1846)

Gyakori gyepszinti faj. Speciális élöhelyi preferenciája nincs. Három példánya lápréti hálózással került befogásra.

Heliophanus cupreus (Walckenaer, 1802)

Gyakori növényzetlakó faj. Egy példánya lombhálózással került elő.

Heliophanus flavipes Hahn, 1832

Nyílt füves élöhelyek gyakori faja. A TT több pontján is elökerült fühálózással.

Macaroeris nidicolens (Walckenaer, 1802)

Fák lombján általánosan elterjedt faj, különösen gyakori lehet tülevelủeken. Két példánya lombozatról került elö.

Marpissa pomatia (Walckenaer, 1802)

Nedves, mocsaras élőhelyek ritka ugrópókja. Két példánya hálózással került befogásra.

Myrmarachne formicaria (De Geer, 1778)

Speciális élőhelyi kötődést nem mutató $s$ egyben leggyakoribb hangyautánzó pókunk. Egy példánya egyeléssel került elö.

Pellenes nigrociliatus (Simon, 1875)

A csigás ugrópók jellemzően azokban a gyérfüvü száraz gyepekben él, ahol a telelö-habitatként, valamint petezsákjainak örzöhelyeként hasznosított üres csigaházak nagy számban hevernek a talaj felszínén. Egy példányát növényzetre szött kórócsiga házban fogtuk.

Philaeus chrysops (Poda, 1761)

Napsütötte száraz élőhelyek tipikus faja. Három példánya egyeléssel került elö homoki gyepben.

Sitticus distinguendus (Simon, 1868)

Ritka, homoki élőhelyekre jellemzö, melegigényes faj. Egy példánya a homokpuszta talajcsapdázása során került elő. Hazánkban ritka. Somogy megyéböl Balatonlelléröl volt korábbi adata (Szinetár 2001). 


\section{A vizsgált élőhelyek értékelése pókfaunájuk alapján}

\section{Homoki gyepek}

A homoki sztyepprétek talajlakó pókfaunája a gyepek viszonylag erőteljes bolygatottsága ellenére faunisztikai szempontból kifejezetten értékes. A fauna egyértelmű és szoros kapcsolatot mutat a Dráva-melléki (Darány, Tóthújfalú, Bélavár), valamint a BelsőSomogyban (Nagybajom) korábban vizsgált homoki élőhelyekkel. A viszonylag kis egyedszámokat produkáló csapdázások során előkerültek a homoki gyepek legtipikusabb karakterfajai. Ezek egy részénél feltételezhető, hogy a Dunántúlon ez a térség a legészakibb előfordulási területe e fajoknak. Ez utóbbi egyértelmü igazolását csak a Kisalföld ez idáig kutatatlan homoki gyepeinek feltárása után lehet egyértelműen kijelenteni. A tipikus homoki fajok mellett emlitést érdemel a tipikusan melegigényes, dél-európai faunaelemnek tekinthető piros ugrópók jelenléte (Phylaeus chrysops) is. E faj a DunaTisza közének homokpusztáin át a Mezőföld, a Dunántúli Középhegység déli kitettségü élőhelyein, sőt sajátos módon a Nyugat-Dunántúlon, a Vendvidék vöröscsenkeszes gyepeiben is jellemző (SzINETÁr 1995). A homoki gyepek legtipikusabb kísérő fajai: Uloborus walckenaerius (Latreille, 1806); Pardosa bifasciata (C.L. Koch, 1834); Oxyopes lịneatus Latreille, 1806; Berlandina cinerea (Menge, 1872); Xysticus ninnii Thorell, 1872; Pellenes nigrociliatus (Simon, 1875); Sitticus distinguendus (Simon, 1868).

\section{Láprétek és magasásosok}

A védett terület legjobb természetességi állapotú, kiemelkedő élő természeti értékekkel rendelkező élőhelyei. Hygro- és fotofil talajlakó pókfajok erős populációi élnek ezekben a gyepekben. Számos, láprétekre jellemző talajlakó pókfaj közül különös értéket képvisel a faunára új Pirata insularis magas abundanciájú jelenléte. Rajta kívül említést érdemel a hazánkból a közelmúltban leírt Pardosa maisa előkerülése is. Ez utóbbi fajnak mostanra a Dunántúlról már hat lelőhelye ismert.

Égeresek, valamint ligeterdő fragmentumok

Annak ellenére, hogy az égeresek nagyon kis kiterjedésben reprezentáltak a területen, mégis fontos élőhelyi szerepet töltenek be jól záródó lombkoronaszintjükkel, valamint humuszban gazdag és vízzel jól átitatott talajuk révén. A nagy nedvesség igényű, tipikus láperdei fajok menedékeinek tekinthetők e kis égeres fragmentumok. Figyelmet érdemel az Arctosa lutetiana előfordulása. Az erdők kis kiterjedésével magyarázható, hogy a szomszédos élőhelyek fajai is jelen lehetnek a mintáikban. Ezzel magyarázható a Zelotes aurantiacus egyetlen példányának előkerülése is. Mint termo- és xerofil faj, a homokpusztáról juthatott az égeres csapdájába.

A terület nem vizes élőhelyekhez kötődő erdőtársulásai

Az egész területhez hasonlóan, ezekre az erdőkre is nagyfokú heterogenitás a jellemző. Területük csekély kiterjedésü a füves élőhelyekhez képest. Nagyobb részüket akácültetvények teszik ki, de mellettük más vegyes fafaj összetételű, többségükben fiatal erdőállományok is vannak. Természetvédelmi értéküket elsősorban, mint erdei habitat jelentik. A hozzájuk kapcsolódó gyűjtések egyik állományban sem tekinthetők kellően reprezentatívnak. A bennük zajló adatgyüjtés elsődlegesen a faunisztikai adatgyüjtést szolgálta. A leggyakoribb talajlakó fajaiknak a Trochosa terricola és a Zelotes apricorum bizonyultak. A védett szurkos torzpók (Atypus piceus) egyetlen hím példányának elökerülése figyelmet érdemel (tölgyes). 


\section{A vizsgált élőhely-típusok talajlakó pókfaunájának összehasonlitása}

A kapott eredmények egyértelműen igazolják a terület nagyfokú heterogenitását. A négy talajcsapdázott élőhely esetében elvégzett ordinációs kiértékelés világosan mutatja a két nedves élőhely nagyfokú hasonlóságát, miközben ezektől és egymástól is élesen elkülönül az égeres, illetve a száraz homoki gyep pókfaunája (5.ábra).

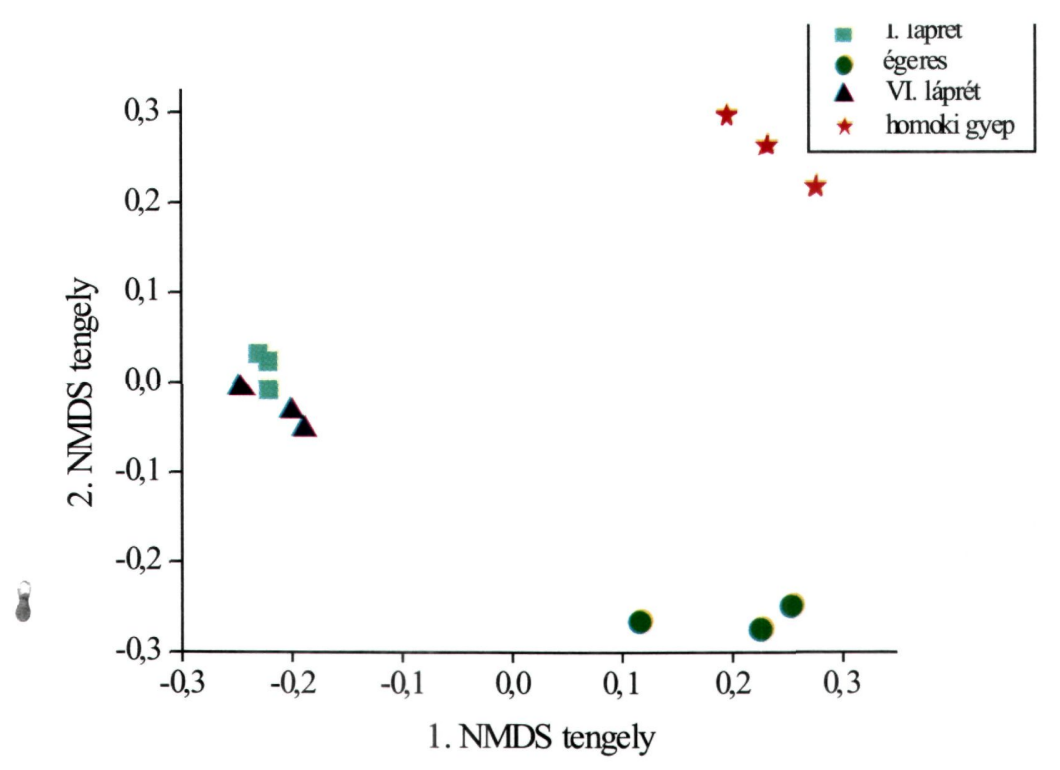

5. ábra: A négy élőhely talajlakó pókfaunájának hasonlósági viszonya.

(négyzet: északi láprét; háromszög: déli láprét; kör: égeres; csillag: száraz homoki gyep)

\section{Az eredmények természetvédelmi vonatkozásai, javaslatok}

A 2001-2002-ben végzett pókfaunisztikai vizsgálatok során a jelentős fajszám mellett kiemelést érdemel a két védett, valamint számos további jó természetességi állapotú élőhelyre jellemző pókfaj előkerülése. Feltétlenül indokolt a vizes élőhelyek tervszerủ megóvása, melyhez több szakember véleményére alapozott kezelési terv alapján kell, hogy sor kerüljön. A későbbiekben fokozott figyelmet kell fordítani arra, hogy a terület jelenlegi állapota ne romoljon. Így szigorúbb védelemben kell részesíteni a lápréteket (2001 nyarán az egyik legértékesebb lápréten vezetékfektetést végeztek), a homoki gyepek természetességi állapotának megőrzése érdekében kerülni kell a szántóvá alakítást, illetve faültetvény telepítést, aktív kezeléssel gátat kell szabni a növényzeti degradációnak (özöngyomok terjedésének), valamint a spontán beerdősülésnek (akác, bálványfa). 


\section{Köszönetnyilvánítás}

Köszönetünket fejezzük ki Dr. Ábrahám Levente programvezetőnek a terület kutatásában való részvétel lehetőségéért, egyes kutatási feltételek biztosításáért, valamint az általa gyüjtött mintákért. Hasonlóképpen köszönet Dr. Kondorosy Elődnek a gyüjtött és átadott anyagokért. A terepi munkák végzése során Szinetár Csaba a Magyar Tudományos Akadémia Bolyai János Kutatási Ösztöndíjában részesült.

\section{Irodalom}

Buchar J. \& RužıčKa V. 2002: Catalouge of spiders of the Czech Republic. - Peres Publishers, Praha 2002. pp. 349.

FARKAS J., SZATMÁRY K. \& STREnNER A. 1998: Ecofaunistical investigations of Collembola, Araneae and Coleoptera in mosaic-like habitats in the Cinege Valley, Hungary. - Opusc. Zool. Budapest, 31: 49-61.

Fuhn I. E., Niculescu-Burlacu F. 1971: Fam. Lycosidae. - Fauna Rep. Soc. Romania, Arachnida 5(3): 1-25.

Gajdos P., Svaton J., Sloboda K. 1999: Catalogue of Slovakian Spiders. - Bratislava pp. 337.

Heimer S., Nentwig W. 1991: Spinnen Mitteleuropas. - Verlag Paul Parey, Berlin und Hamburg, p.500.

KEREKES J. 1988: Faunistic studies on epigeic spider community on sandy grassland (KNP). - Act. Univ. Szeged. Act. Biol. 34:113-117.

LOKSA I. 1969: Pókok I.-Araneae I. - Fauna Hungariae 97 Akadémiai Kiadó, Budapest. pp.133.

Loksa I. 1972: Pókok II. - Araneae II. Akadémiai Kiadó, Budapest. pp.112.

Nentwig W., Hänggi A., Kropf C. \& Blick T. 2003: Central European Spiders - Determination Key. Version 8.01. 2003./ http:/www.araneae.unibe.ch/

RoBerts M.J. 1995: Spiders of Britain and Northern Europe - Harper Collins Publishers. pp. 383.

SAMU F., SzINETÁr Cs. 1999: Bibliographic check list of the Hungarian spider fauna. - Bull. Br. arachnol. Soc. 11 (5): $161-184$.

SzINETÁr Cs. 1992: A Boronka-melléki Tájvédelmi Körzet pókfaunája - Dunántúli Dolgozatok Természettudományi Sorozat 7: 331-345.

SzINETÁr Cs. 1998: A Dráva mente pókfauna (Araneae) kutatásának faunisztikai eredményei. - A Dráva mente állatvilága, II. - Dunántúli Dolgozatok Természettudományi Sorozat 9: 97-110.

SzINETÁr Cs. 2001: Somogy megye pókfaunája (Araneae) - Natura Somogyiensis I. 57-70.

SzINETÁR Cs. 2001: Magyarország pókfaunájảnak taxonómiai törzsadattára. Kézirat.

SzInETÁr Cs., GuitPreCHT G. 2001: A Pardosa maisa Hippa \& Mannila, 1982 elökerülése Magyarországon (Araneae, Lycosidae) Folia Musei Historico-Naturalis Bakonyiensis. 17-1998 (2001); 87-96. 


\title{
The results of the investigation of the spider fauna (Araneae) of the Látrányi Puszta Nature Conservation Area
}

\author{
Csaba Szinetár and BaLÁzs KereszTes
}

The examination of the fauna of the Látrányi Puszta Nature Conservation Area, located close to the Southern shore of Lake Balaton, was carried out between 2000 and 2002. Targetting mostly ground-dwelling species, the examination carried out via Barber pitfall-trapping, handpicking and sweep-netting yielded 152 spider species including Pirata insularis, which is new to the Hungarian spider fauna. It is typically indigenous to fen meadows.

The hitherto known spider fauna of Somogy county was enlarged by 24 newly detected species including two protected ones: Atypus piceus and Dolomedes fimbriatus. The high number of indigeneous species is probabaly due to the fact that the relatively small area is rather heterogenic in the composition of its fauna. What's partciularly valuable is the simultaneous presence of species typical of both dry sandy grasslands and of fen meadows. Figure 5. illustrates the similarity between the specimens yielded by the four Barber pitfall-trappings. It is clear to see that although the two fen meadows show a striking similarity (see the squares and the triangles), the areas with alder (see the circles) and the dry sandy grasslands (see the stars) are distinctively different. In spite of their marked perturbation, the sandy grasslands have a rather valuable fauna composition in terms of the ground-dwelling fauna which is clearly and closely related to to sandy habitats examined earlier in the area Dráva-mellék (Darány, Tóthújfalú, Bélavár) and in Belsö-Somogy (Nagybajom). Characteristic species of the fauna: Uloborus walckenaerius (Latreille, 1806); Pardosa bifasciata (C.L. Koch, 1834); Oxyopes lineatus Latreille, 1806; Berlandina cinerea (Menge, 872); Xysticus ninnii Thorell, 1872; Pellenes nigrociliatus (Simon, 1875); Sitticus distinguendus (Simon, 1868). Fen meadows and areas with high segde are the habitats of the protected area which have invaluable and unique values and which are best preserved in their original conditions. Large populations of hygro- and photophile ground-dwelling spiders live in these grasslands. The micro-climatic conditions of the ground surface in fen meadows are different from what we can find in shore reeds and sedgy areas at Lake Balaton, though they lie surpisingly on one another. 